\title{
MRP Framework to Increase Production Operations Performance. An Applied Study on the Egyptian Manufacturing Pharmatheutical Companies Emad Elwy Habib
}

Lecturer (Ph.D.), Management and Systems Department, Faculty of Management Sciences, Modern Sciences and Arts University MSA, Egypt.

\section{Abstract:}

Materials Requirements Planning (MRP) is currently one of the most popular manufacturing frameworks. Based on 13 manufacturing Pharmatheutical Company in Egypt in Great Cairo survey, the researcher found that the degree of the MRP positive implementation intense Pharmatheutical manufacturer's production operations performance, Ensures the availability of materials, components, products. Enhances production operations planning and controlling, customer delivery, maintains the optimal possible level of inventory, and plan manufacturing activities, delivery schedules, and purchasing activities. MRP creates synergy and attains better production and operations performance, and resulted in wide acceptance in the Egypt manufacturing Pharmatheutical field. 


\section{جاممة تناة السويسه - كلية التجارة الإلسماعيلية}

MRP Framework to Increase Production Operations Performance....

Emad Elwy Habib

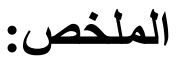

يعد تخطيط الإحتياجات من المواد في العقود الأخيرة من أهم المداخل

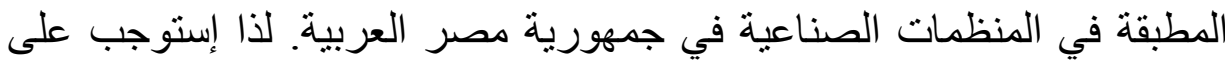
الباحث إعداد إستمارة إستقصاء وقام بتوزيعها على عدد بات إ شركة من الثركات

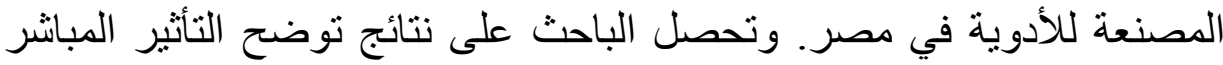
بين زيادة درجة تطبيق مدخل تخطيط الإحتياجات من المواد والإداء الإنتاجي

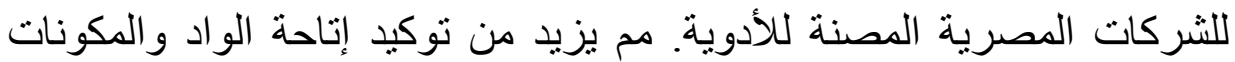
وقطع الغيار والمنتجات. ووجد الباحث أيضاً أن تبني مدخل تخطبط الإحتياجات

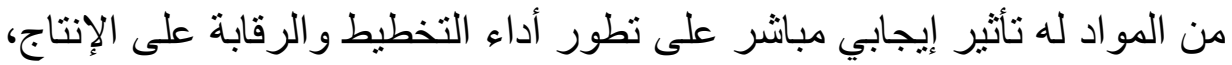

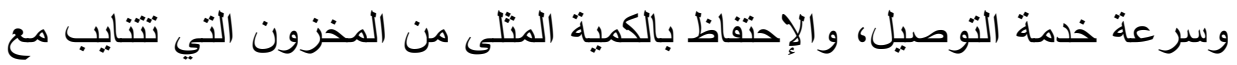

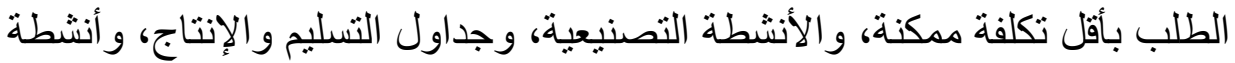

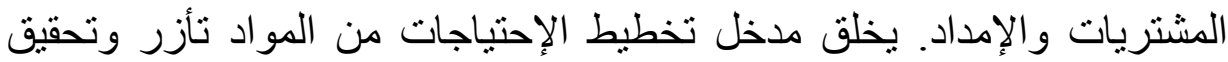

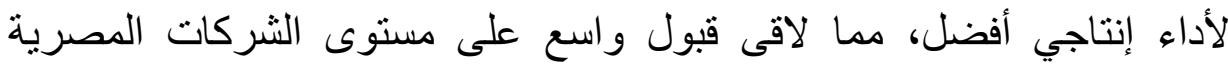
المصنعة للأدوية. 
MRP Framework to Increase Production Operations Performance....

Emad Elwy Habib

KEY WORDS Material Requirements Planning MRP/MRP II/MRP III, Bill of Materials (BOM), Production Operations Planning Performance (POP), Production Operations controls Performance (POC), Production Operations Performance.

Research methodology the research investigates the degree of MRP framework implementation impact on the manufacturing Pharmatheutical companies' synergy and production performance throughout production planning and control in Egypt, has been conducted based on a pilot study in the manufacturing Pharmatheutical sector in Egypt. The research covers two sections, the first section encompasses a detailed literature review concerned with Materials Requirement Planning (MRP) components. The second section, investigates and identifies the results of an empirical study throughout a limited survey that has been distributed to 13 manufacturing Pharmatheutical company in Egypt in Great Cairo.

The research was targeting 160 managers, and the received surveys are 122 respondents. The questions in the questionnaire were answered on the 5-point Likert-scale, corresponding to the degree of agreement with the statement. It was recognized that further research is necessary to establish the exact nature of the causal relationships between proposed MRP Model and applications and another 
MRP Framework to Increase Production Operations Performance....

Emad Elwy Habib

manufacturing sectors in Egypt, in order to gain insights into practice elsewhere.

\section{RESEARCH PROBLEMS}

Throughout the pilot study in the manufacturing Pharmatheutical companies in Egypt the exploratory research concluded the sector's problems in the following:

1. The companies' production planning problems: It is hard to know the ending date of the production of a certain component which makes it difficult to determine the time of delivery of the product to the customer.

2. The companies' inventory and production control problems:

The Bill of material problems when there is a request from a customer to produce a certain quantity of products a purchase order for raw materials is made and some raw material or components may be forgotten due to the large number of these raw materials or components resulting in delaying of the production of the requested products. And the purchase order is done directly without reference to raw materials inventory to know the existing quantity of raw materials and this resulting in storing large quantities of raw materials which increasing the raw materials inventory holding cost, and in addition, materials inventory is used without checking if this quantity is reserved by the production Department for the benefit of a particular customer, leading to 
MRP Framework to Increase Production Operations Performance....

Emad Elwy Habib

delay in production of raw material for this particular customer which costs the company penalty clause payment for this delay.

\section{Research Objectives}

1. Examining production operations management practices in the Egyptian Pharmatheutical Companies.

2. Revealing the progress of MRP application

3. Investigating the relationships among MRP technique components and its impact on production operations planning performance.

4. Investigating the relationships among MRP technique components and its impact on production operations control performance.

5. Presenting insightful recommendations for further efficiency improvement.

\section{Research hypothesis}

Several researchers have theoretically shown that JIT and MRP integrated system is more effective due to complementary effects (Lee, 1992). Benton and Shin (1998) believe a combined MRP and JIT system reflects a more effective manufacturing environment. Based on the literature and interviews with managers and academicians, we developed the following hypotheses.

H1: Egyptian Pharmatheutical companies with a higher level of MRP implementation have better production

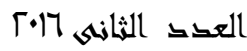

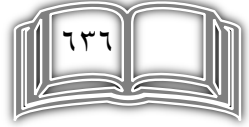

المجلك السابع 
MRP Framework to Increase Production Operations Performance....

Emad Elwy Habib

operational planning performance than those with a lower level of MRP implementation.

H2: MRP implementation in the Egyptian Pharmatheutical companies has a higher impact on production operational planning performance (POP) than Production Operations Control Performance.

H3: MRP have a significant positive impact on the Production operations performance in the Egyptian Pharmatheutical companies.

\section{Introduction}

Materials Requirements Planning (MRP) is an integrating framework that functions efficiently for production scheduling, inventory control, and bill of materials in order to reduce ordering and setup costs, improve quality of production work flow processes, decrease customer overall delivery time that encompasses lead time, run time and usage time, and facilitates continuous flow of the required raw materials, and components on the production lines.

Inside of the most recent 4 decades, Manufacturing Resource Planning (MRP) frameworks have immediately developed from essential materials prerequisite arranging to today's endeavor asset arranging ERP coordinated bundles that live on customer/ structural management throughout a backward integrative frameworks to bolster fabricating asset arranging that have developed by leaps and bounds from

العقد الثزانى 17

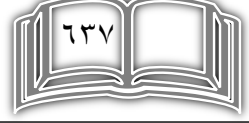

المجلك السابع 
MRP Framework to Increase Production Operations Performance....

Emad Elwy Habib

fundamental materials necessity arranging MRP to today's modern expanded endeavor combination bundles that live on customer structural management. Empirical study of Materials Requirements Planning (MRP) has historically focused on the identification of factors that impact the overall production performance (Salaheldin, 2004). Materials Requirements Planning first examined the benefits of MRP at the early 1980 's, then followed by Subsequent studies in the 1990's and 2000's which showed that MRP can improve quality; shorten lead times; reduce WIP; improve Production Planning (PP), schedule and control; lower inventory level; increase productivity and customer service; reduce operations cost and improve cooperation among department.

The Development of Manufacturing Resource Planning definitions MRPI Materials Requirement Planning, a computer-based system for managing inventory and production schedules. This approach to materials management applies to large job-shop situations in which many products are manufactured in periodic lots in several processing steps. It does not apply to continuous-flow-type manufacturing systems. MRPII Manufacturing Resource Planning, a framework in which the whole generation environment is assessed to permit expert timetables to be balanced and made in view of criticism from current creation/buy conditions.

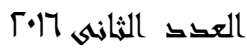

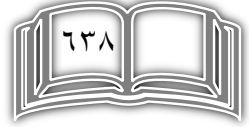

المجلك السابع 
MRP Framework to Increase Production Operations Performance....

Emad Elwy Habib

In the administration of creation frameworks, generation arranging speaks to the center action managing how and when to deliver, considering client requests and material and asset accessibility while going for minimizing creation time and expenses, efficiently sorting out the utilization of assets and expanding efficiency in the creation framework. To this end, generation arranging can recommend to utilize the asset accessibility of an offered period to fulfill the interest of different periods. Reckoning of generation prompts stock expenses, parts created ahead of time need to hold up in stock, while ungreediness' may prompt punishment costs, late conveyance of the requests or lost demand. Moreover, the amount delivered in a given period affects the asset and material utilization and therefore the generation costs. This issue can be systematically defined by method for variables speaking to the choices to be taken and of limitations speaking to assets accessibility, priorities and due dates. Alfieri, A., Tolio, and Urgo, M. (2012). MRP frameworks which are composed assembling data frameworks used to enhance material and logistics arranging and administration. Later, MRPII, or assembling asset arranging, took after and fused the monetary and bookkeeping parts of business exercises. At the point when MRP wandered out to dispersion frameworks, appropriation prerequisite arranging DRP could be utilized as
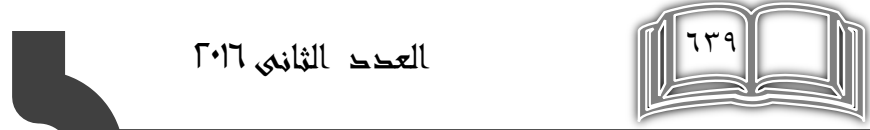

المجلك السابع 
MRP Framework to Increase Production Operations Performance....

Emad Elwy Habib

an included module to calendar conveyance and stock control in circulation channel Jyh, H. (2008).

The researcher's study targeting to discover the creation arranging, stock control, and bill of materials issues in a furniture organization and developing so as to tackle these issues MRP framework with particular destinations to take care of the production and operations performance throughout planning and control performance in the manufacturing Pharmatheutical companies in Egypt. 
MRP Framework to Increase Production Operations Performance....

Emad Elwy Habib

\section{Literature review}

Material Requirements Planning MRP I is a system for managing inventory and production schedules. This approach to materials management applies to large job-shop situations in which many products are manufactured in periodic lots in several processing steps. It does not apply to continuous flow type manufacturing systems. (Bedworth \& Bailey, 1987), and it is a framework based production planning and inventory control system used to manage manufacturing processes. Although it is not common nowadays, it is possible to conduct MRP by hand as well. According to Monk, E. and Wagner, B., (2006) \&Waldner, Jean-Baptiste (1992), Manufacturing organizations, despite of their products, face a common problem which is shortening the delivery time taken to replenish customers' requirements. This means that accurate planning and scheduling system is required. Manufacturing companies need to control the types and quantities of materials they purchase, plan which products are to be produced and in what quantities and ensure that they are able to meet current and future customer demand, all at the

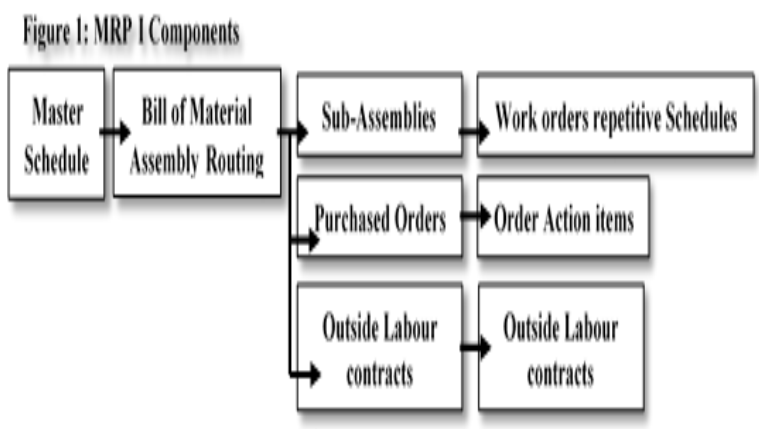

Source: Nonk, E. and Nagner, B., (2006) \& Waldner, Jean-Baptiste (1992)

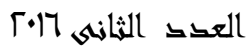

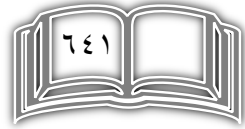

المجلك السابع 
MRP Framework to Increase Production Operations Performance....

Emad Elwy Habib

lowest possible cost. Decisions in any of these fields will make critical to the company, if a company purchases insufficient quantities of an item used in manufacturing, or the wrong item, they may be unable to meet contracts to supply products by the agreed date, and if a company purchases excessive quantities of an item, money is being wasted - the excess quantity ties up cash while it remains as stock and may never even be used at all. This is a particularly severe problem for Pharmatheutical manufacturers and companies with very short product life cycles. However, some purchased items will have a minimum quantity that must be met, therefore, purchasing excess is necessary. According to Cheng, $\mathrm{P}$. (1997), MRP I Materials Requirement Planning, a computerbased system for managing inventory and production schedules. This approach to materials management applies to large job-shop situations in which many products are manufactured in periodic lots in several processing steps. It does not apply to continuous-flow-type manufacturing systems.

Beginning production of an order at the wrong time can cause customer deadlines to be missed MRP is a tool to deal with these problems. It

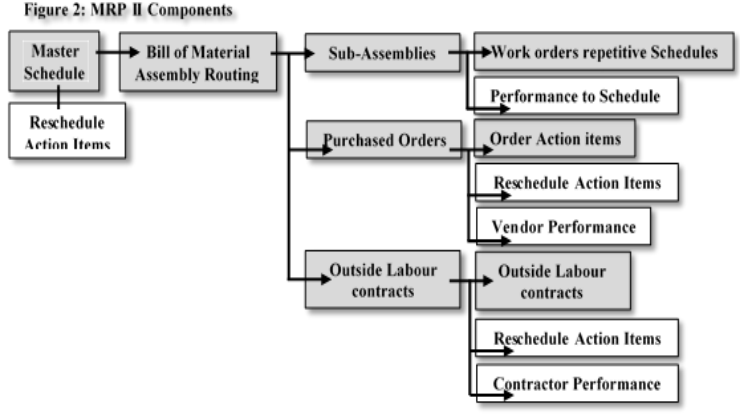

Source: Monk, E. and Wagner, B., (2006) \&Waldner, Jean-Baptiste (1992)

العق

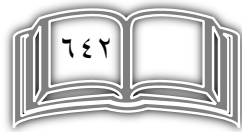

المجلد السابع 
MRP Framework to Increase Production Operations Performance....

Emad Elwy Habib

provides answers for, What, how many, and when materials are required, MRP can be applied both to items that are purchased from outside suppliers and to sub-assemblies, produced internally, that are components of more complex items. MRP framework is intended to simultaneously meet three objectives: Ensure materials and products are available for production and delivery to customers. Maintain the optimal possible level of inventory. Plan manufacturing activities, delivery schedules and purchasing activities.

Manufacturing Resources Planning MRP II process is a system in which the entire production environment is evaluated to allow master schedules to be adjusted and created based on feedback from current production/purchase conditions. Bedworth \& Bailey, (1987), According to Monk, E. and Wagner, B., (2006) \&Waldner, Jean, Baptiste (1992), is a process to assist planners in tracking some of the problems associated with inventory control, some kind of 'feedback loop' not only to automatically re-schedule certain items (when possible), and avoid excessive manual effort in controlling the process, but to detect and report performance that is 'out of spec' (such as a vendor performance report to track on-time delivery performance). This 'feedback loop' is the defining components for an 'MRP II' system. Jha, V. (2012), argued that Manufacturing Resource Planning MRP II represent the Push type of production control. Thus according 
MRP Framework to Increase Production Operations Performance....

Emad Elwy Habib

to Moustakis, Vassilis, (2000), MRP has evolved to become a component of a MRPII system. Technically, MRPII extends MRP and links it with the company's information resources such as human resource, information system, financial management, accounting, sales, etc.. According to Salaheldin Ismail, (2005). Still, with automated rescheduling capabilities for work orders and/or repetitive build schedules, and 'reschedule action' reports for purchase orders and outside contracting, the amount of actual analysis is reduced significantly. Other information, such as vender profiles performance reports and process actual capacity throughout efficiency and utilization reports, also help to measure the 'performance to plan' capability of the manufacturing plant. Even when the production plan is running at optimum performance, companies still often have serious problems with the manufacturing process. 'Hidden Cost' issues associated with manufacturing increase the total cost of manufacturing, but are extremely hard to track. Some of these 'Hidden Costs' can be caused by excessive Purchase orders PO rescheduling or excessive 'crash buy' programs, excess and/or obsolete inventory, or planning problems that cause incorrectly stocked finished goods (too much of one, not enough of the other) that result in shortages. as well as material shortages and excessive 'kitting' of common components. In addition, potential revenue losses from excessively long customer order lead 
MRP Framework to Increase Production Operations Performance....

Emad Elwy Habib

times, or poor on-time customer delivery performance, are real problems, but very difficult to track and measure. As such, none of these problems are tracked nor reported by any 'standard MRP I or MRP II systems.

To help solve these problems, and improve the company's competitiveness and profitability, beyond existing capabilities, Manufacturing Resource Planning (MRP II) is defined by APICS (American Production and Inventory Control Society, 1957) as a method for the effective planning of all resources of a manufacturing company. Ideally, it addresses operational planning in units, financial planning in dollars, and has a simulation capability to answer "what-if" questions and extension of closed-loop MRP. This is not exclusively a software function, but a marriage of people skills, dedication to data base accuracy, and computer resources. It is a total company management concept for using human resources more productively. MRP II integrates many areas of the manufacturing enterprise into a single entity for planning and control purposes, from board level to operative and from fiveyear plan to individual shop-floor operation. As shown in figure (2), MRP II, builds on closed-loop Material Requirements Planning (MRP) by adopting the feedback principle but extending it to additional areas of the enterprise, primarily manufacturing-related. 
MRP Framework to Increase Production Operations Performance....

Emad Elwy Habib

Rusănescu, M. (2014) Material necessities arranging (MRP) is seen as a standout amongst the most broadly utilized frameworks for creation arranging and control in industry, material Requirements Planning - the new way of life on production and inventory administration, which has demonstrated the potential and advantages of MRP. As we probably are aware, the frameworks speak to sets of components that are interconnected, connecting, going about in general to achieve an objective. We likewise realize that any framework is seen as a subsystem inside of the association. Our methodology is that inside of associations as MRP framework assists the association with achieving the goals, cooperating with different subsystems. It performs the accompanying capacities: Stock administration, item information administration, area/parcel administration, limit necessities and materials prerequisite arranging, and, to some degree, money due, records payable, and deals examination. 
MRP Framework to Increase Production Operations Performance....

Emad Elwy Habib

Materials Requirements Planning MRP III, Monk, E. and Wagner, B., (2006) \&Waldner, Jean-Baptiste (1992), implied that MRP III process starts with an Accurate Demand Forecast that drives the entire manufacturing business. Using the best possible demand forecast, a Master Schedule is developed. Ideally the total number of master scheduled items will be minimized, so that the MRP system can appropriately generate build a general master schedule throughout the production aggregate plan and products trees, the MRP

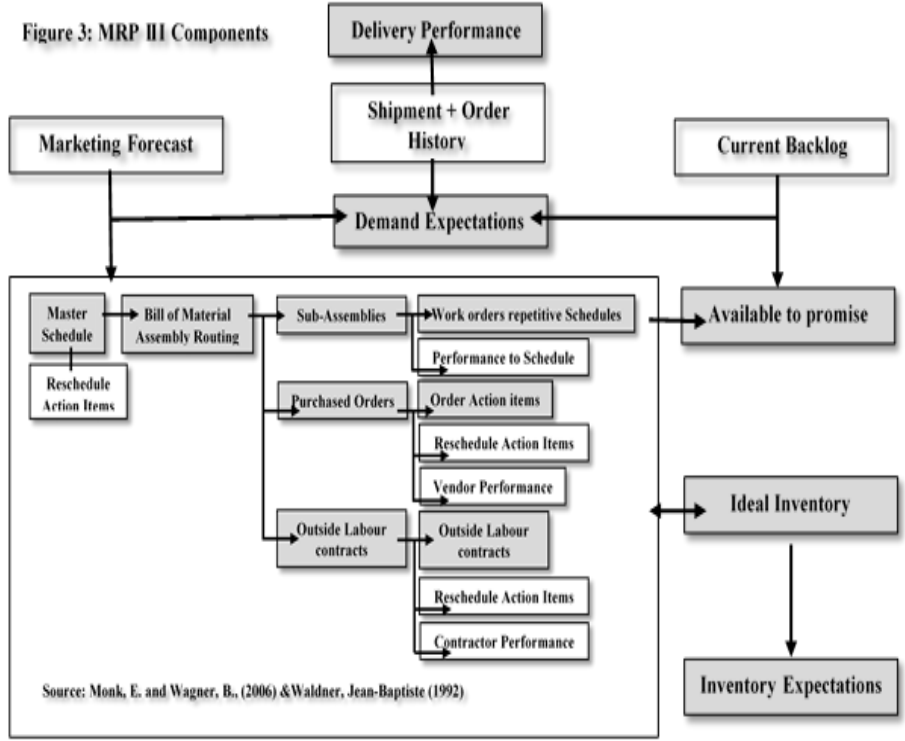
III system derives the individual component and assembly requirements, and recommends new purchase orders, just like a standard MRP system, and also generates recommended purchase order reschedules, and automatically reschedules non-master scheduled assemblies based on the availability of components/resources and material requirements, just like an MRP II system. As shown in figure 3 The MRP III system 
MRP Framework to Increase Production Operations Performance....

\section{Emad Elwy Habib}

also monitors and reports vendor performance and 'performance to plan' by the assembly line, similar to an MRP II system. However, to minimize the total amount of detail information, the MRP III system concentrates on only reporting those items that fall outside of the allowed tolerances, thus minimizing the number of reported items.

When the MRP system has been fully integrated with the Order Management system, it becomes possible to calculate Available to Promise inventory, based on a combination of existing order backlog, the current inventory, and the projected availability of a product over time as it is built from the current production schedule. In this way, if a customer orders a product within lead time, and delivery is already promised to another customer, order management personnel can use this information to negotiate a realistic delivery schedule with the customer. Also, delivery reschedules would become easier to manage, since order management personnel can view the current 'available to promise' inventory, and use this information to determine when partial or full shipments could be re-scheduled. In all likelihood, there will be available inventory to ship ahead of schedule, should the customer need to perform a crash buy. An MRP III system must therefore include the ability to view the 'available to promise' inventory, based on current inventory, current backlog, and the current production plan. 
MRP Framework to Increase Production Operations Performance....

Emad Elwy Habib

Finally, the MRP III system bases its operating parameters on the principles of Bandwidth Management, dynamically adjusting parameters such as lead times and 'ideal inventory' according to the historic data (when needed), and measuring performance to a set of statistically derived 'control bands', rather than fixed parameters. The 'MRP III' system then generates exception reports for those items that fall outside of the control bands, and automatically maintains as much of the manufacturing planning process as possible, with little or no human intervention.

A process such as MRP III would help to eliminate certain kinds of errors that currently plague manufacturing businesses on a nearly universal level. By far, the greatest single factor in ruining a perfectly good manufacturing plan is the tendency for the Demand Forecast to change on a regular basis, typically inside planning lead time. Or, the Demand Forecast may be completely useless for manufacturing purposes, forcing the person responsible for the master schedule to literally generate his own forecast in an attempt to predict what the demand actually will be. Often times, a combination of both of these conditions exists, where the marketing forecast is so inaccurate as to make it useless, forcing the master scheduler to perform this task of generating a forecast.
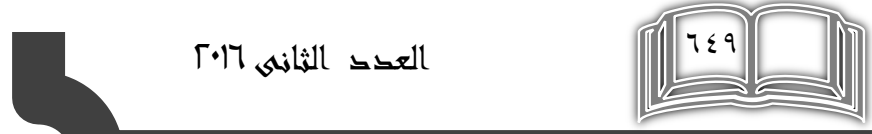

المجلك السابية 
MRP Framework to Increase Production Operations Performance....

Emad Elwy Habib

MRP production operations application and performance

Previous MRP studies concentrated on identifying the most prominent factors that has a major impact on the manufacturing companies' overall performance (Salaheldin, 2004). The common agreement is that management supportive attitudes, marketing strategies, organizational environment, development and training, suppliers' development and support, IT systems proficiency, company size and age are main success factors. Sponsored by APICS, Schroeder et al. (1981), Anderson et al. (1982), and White et al. (1982) first examined the benefits of MRP. Subsequent studies (Wilson et al., 1994; Sum et al., 1995; Salaheldin and Francis, 1998; Petroni and Braglia, 1999; Lau et al., 2002; Rabinovich et al., 2003;) concluded that MRP improves quality; decrease lead times; reduce WIP; improve Production Planning (PP), schedule and control; lower inventory level; increase productivity and customer service; reduce operations cost and improve cooperation among department. Murphy and Simon (2002) and Hunton et al. (2003) added that MRP has a significant direct and positive impact on the operational and financial performance measures manufacturing companies. 


\section{The research framework:}

\author{
Figure (4) the research \\ framework:
}

Production Operations Management

Performance Measures:

\section{Production Operations Planning}

performance measure:

2.1. Effectiveness of production planning

2.2. Accuracy of demand forecasting

2.3. Information sharing degree of cross-function

2.4. Flexibility of production planning

2.5. Data accuracy of production planning

2.6. Small lot sizing

2.7. JIT purchasing

2.8. Pull production line

2.9. Cross-training and multifunction employee

2.10 . '5S' activities: workplace organization and standardization

2.11. KANBAN system

2.12. Production Rule and cycle (e.g. EPQ)

2.13. Total production maintenance (TPM)

2.14. Effectiveness of production planning

2.15. Master Production Scheduling

2.16. Capacity Planning

2.17. Plant Layout

2.18. Companies with a higher level of MRP implementation have better production operational planning performance than those with a lower level of MRP implementation.

1.1. Demand forecasting/order management

1.2. Master Production Scheduling (MPS)

1.3. Rough Cut Capacity Planning (RCCP)

1.4. Materials Requirement Planning (MRP)

1.5. Capacity Requirement Planning (CRP)

1.6. Shop flow scheduling and control

1.7. Inventory management

1.8. Purchasing/supplier management

1.9. Equipment maintenance management

1,10. Basic data management

1.11. Forecasts (Independent Demand)

1.12. Bill of Material (Dependent Demand)

1.13. Lead Time (by component)

1.15. Ordering Rules and inventory cycle (e.g. EOQ)

1.16. Production routing (represent the steps and associated times that are required to make an item).
2.19. When MRP are implemented concurrently, it has more impact on the Production operations planning performance than production operation control.

3. Production Operations Control performance measure:

3.1. Accuracy of completing production plan

3.2. Set-up time reduction

3.3. Quality circle and TQM

3.4. Scheduling stability

3.5. level of WIP reduction

3.6. Degree of on-time delivery

3.7. Satisfaction degree of quality

3.8. Operations cost

3.9. Breakdowns and maintenance control

3.10. Bottlenecks control.

3.11. Inventory and stock control.

3.12. Internal bound logistics control

3.13. companies with a higher level of MRP implementation have better production operational control than those with a lower level of MRP implementation.

Source: The researcher Based on Lau et al., 2002; Petroni and Braglia, 1999; Rabinovich et al., 2003; Salaheldin and Francis, 1998; Sum et al., 1995; Wilson et al., 1994, Chen, Z., \& Shang, J. S. 2008

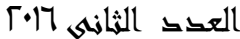

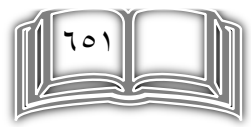

المجلد السابي 
MRP Framework to Increase Production Operations Performance....

Emad Elwy Habib

\section{Empirical Study:}

The questionnaire developed in this research was intended to construct a model of current practices of MRP, Production Operations Planning and Controlling Performance; that examined the research objectives through three indicators, where each indicator represents one of the questionnaire sectors. The Statistical Package for Social Sciences (SPSS 22) and AMOS 21 have been used.

Confirmatory factor analysis (CFA) was first conducted to test how well the measured variables represent the constructs. The key advantage is that the researcher can analytically test a conceptually grounded theory explaining how different measured items represent important business measures. When CFA results are combined with construct validity tests, the researcher can obtain a better understanding of the quality of their measures. The construct validity is the extent to which a set of measured items actually measures the construct. The model fit is assessed in terms of ten indices: Normed Chi-Square with cut-off values less than (5), goodness-of-fit index (GFI), Adjusted Goodness of Fit Index (AGFI), Normed Fit Index (NFI), Relative Fit Index (RFI), Incremental Fit Index (IFI), Tucker Lewis Index (TLI), Comparative Fit Index (CFI), Root Mean Square Residual Approximation (RMSEA), Root Mean Square Residual (RMR), and The average variance extracted with cut-off 
MRP Framework to Increase Production Operations Performance....

Emad Elwy Habib

values greater than (0.5). A model is considered to be satisfactory if CFI $>0.90$, GFI $>0.90$ and RMSEA $<0.10$ (Hair et al., 2010).

The researcher conducted on a hand an initial multiGroup analysis (Confirmatory factor and Path analysis) that identified the observed, endogenous variables and the unobserved, exogenous variables that resulted in a significant relationship between the following constructs: MRP and Production Operations planning (POP) with 91.6\%, MRP and production Operations Controlling (POC) with $81 \%$, and Production Operation Planning and Controlling 74.9\%. On the other hand, On the other hand, the researcher conducted also a final Multi Group analysis (Confirmatory factor and Path analysis) after excluding low estimate sub-construct, with the fit measured variables represents the constructs, as the following: MRP and Production Operations planning (POP) with 79\%, MRP and production Operations Controlling (POC) with 73\%, Production Operation Planning and Controlling $61 \%$. The final Multi-group analysis (confirmatory factor and path analysis) confirmed the validity of the model used, according to Table (1), the researcher can conclude the following:

1. All standardized regression weights (factor loading) are greater than 0.50 , which means that all measured variables, 


\section{جاممة قناة السويسى - كلية التجارة الإلسماعيلية}

MRP Framework to Increase Production Operations Performance....

Emad Elwy Habib

are statistically significant, i.e., the measured variables represent the constructs.

2. t-test for all measured variables is significant at a level of significance less than (0.001), which shows the importance of the observed variables in measuring the impact of MRP implementation Measures on Production Operations Management Performance Measures which encompasses production Operations Planning Performance Measures (POP), and Production Operations Control Performance Measures (POC).

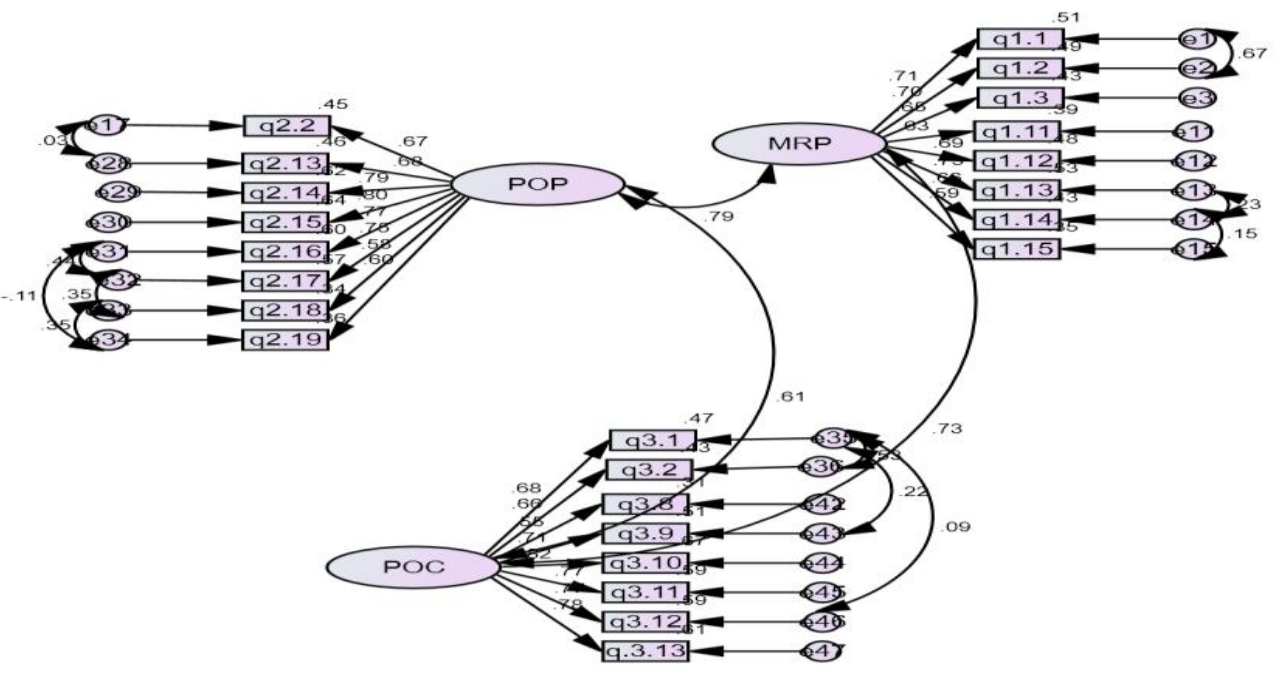

Figure (5): The Final Multi-Group analysis (Confirmatory Multifactor and Path analysis for a measurement model

العك 
MRP Framework to Increase Production Operations Performance....

Emad Elwy Habib

Table (1): Multi-Group for Confirmatory factor analysis and Path Analysis by standardized and unstandardized regression weights

\begin{tabular}{|c|c|c|c|c|c|c|c|}
\hline \multicolumn{3}{|l|}{ Path } & \multirow{2}{*}{\begin{tabular}{|l|}
$\begin{array}{l}\text { Standardized } \\
\text { estimate }\end{array}$ \\
0.712 \\
\end{tabular}} & \multirow{2}{*}{\begin{tabular}{|l|}
$\begin{array}{l}\text { Unstandardized } \\
\text { estimate }\end{array}$ \\
1.000
\end{tabular}} & \multirow[t]{2}{*}{ S.E. } & \multirow[t]{2}{*}{$\begin{array}{l}\text { t_test: } \\
\text { CR }\end{array}$} & \multirow[t]{2}{*}{$\begin{array}{l}\text { Significant } \\
\text { level }\end{array}$} \\
\hline q1.1 & <--- & MRP & & & & & \\
\hline $\mathrm{q} 1.2$ & <--- & MRP & 0.701 & 0.861 & 0.071 & 12.052 & $* * *$ \\
\hline$q 1.3$ & <-- & MRP & 0.653 & 0.879 & 0.138 & 6.380 & $* * *$ \\
\hline$q 1.11$ & <--- & MRP & 0.628 & 0.781 & 0.127 & 6.148 & $* * *$ \\
\hline$q 1.12$ & <-- & MRP & 0.693 & 0.879 & 0.130 & 6.754 & $* * *$ \\
\hline$q 1.13$ & <--- & MRP & 0.730 & 0.868 & 0.123 & 7.082 & $* * *$ \\
\hline$q 1.14$ & <-- & MRP & 0.659 & 0.742 & 0.116 & 6.377 & $* * *$ \\
\hline$q 1.15$ & <--- & MRP & 0.588 & 0.709 & 0.123 & 5.747 & $* * *$ \\
\hline q2.19 & <--- & POP & 0.602 & 0.836 & 0.146 & 5.711 & **** \\
\hline q2.18 & $<--$ & POP & 0.584 & 0.848 & 0.152 & 5.565 & $* * *$ \\
\hline q2.17 & <--- & POP & 0.753 & 1.295 & 0.186 & 6.961 & $* * *$ \\
\hline $\mathrm{q} 2.16$ & <--- & POP & 0.774 & 1.319 & 0.185 & 7.115 & $* * *$ \\
\hline$q 2.15$ & $<--$ & POP & 0.797 & 1.213 & 0.166 & 7.318 & $* * *$ \\
\hline q2.14 & |<-- & POP & 0.785 & 1.397 & 0.193 & 7.227 & $* * *$ \\
\hline q2.13 & <--- & POP & 0.681 & 1.064 & 0.163 & 6.544 & $* * *$ \\
\hline $\mathrm{q} 2.2$ & <--- & POP & 0.674 & 1.000 & & & \\
\hline q3.1 & <--- & POC & 0.684 & 1.000 & & & \\
\hline q3.2 & $<--$ & POC & 0.659 & 1.023 & 0.112 & 9.166 & $* * *$ \\
\hline q3.8 & <--- & POC & 0.554 & 0.798 & 0.148 & 5.381 & $* * *$ \\
\hline q3.9 & <--- & POC & 0.711 & 1.107 & 0.144 & 7.662 & $* * *$ \\
\hline q3.10 & $<--$ & POC & 0.817 & 1.319 & 0.173 & 7.642 & $* * *$ \\
\hline q3.11 & $<--$ & POC & 0.766 & 1.074 & 0.149 & 7.232 & $* * *$ \\
\hline q3.12 & <--- & POC & 0.770 & 1.061 & 0.139 & 7.630 & $* * *$ \\
\hline q.3.13 & <--- & POC & 0.779 & 0.955 & 0.130 & 7.334 & $* * *$ \\
\hline
\end{tabular}

*** Significant at level less than (0.001). a: Initial value for the possibility of solving equations.

3. As a result of Squared Multiple Correlations, the average variance extracted, for the variables that have less than $(0.50)$, then they have been excluded from: MRP: Master Production

العك

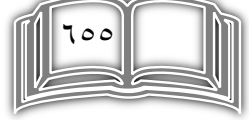

المجلد السابي 
MRP Framework to Increase Production Operations Performance....

Emad Elwy Habib

Scheduling (MPS), Rough Cut Capacity Planning (RCCP), Forecasts (Independent Demand), Bill of Material (Dependent Demand), Ordering Rules and inventory cycle (e.g. EOQ), and Production routing, that have less than (0.50), then they have been excluded from the MRP Implementation measures construct. And POP: Accuracy of demand forecasting, and Total production maintenance (TPM), that have less than (0.50), then they have been excluded from the Production Operations Planning Performance measures (POP) construct. POC: Accuracy of completing production plan, Set-up time reduction, and Operations cost.

\section{Measuring the Goodness of Fit of the (CFA) model}

From table (1), the researcher revealed that:

1. All the goodness of fit tests of the model showed significant results or i.e., the majority of indicators at acceptable limits or near to cut-off values, and then the possibility of matching the actual form of the model estimated.

2. the values of Root Mean Square Residual (RMR) and Root Mean Square Residual Approximation (RMSEA) less than (0.10), which indicates a close fit of the model in relation to the degrees of freedom.

3. The mean variance extracted for all latent constructs is 0.85827 , i.e., there is adequate convergent validity.

العقد الثزانى 17

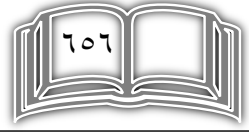

المجلك السابع 
MRP Framework to Increase Production Operations Performance....

Emad Elwy Habib

Table (2): The Goodness of Fit Indices of the Multi-Group for Confirmatory factor analysis and Path Analysis

\begin{tabular}{||l|l|}
\hline Chi-Square & $\mathbf{5 0 2 . 2 5 2}$ \\
\hline Degree of Freedom & 238 \\
\hline Level of Significance & $\mathbf{0 . 0 0 0}$ \\
\hline Normed Chi-Square & $r .110$ \\
\hline Root Mean Square Residual (RMR) <0.10 & $\mathbf{0 . 0 4 2}$ \\
\hline Goodness of Fit Index (GFI) & $\mathbf{0 . 9 4 0}$ \\
\hline Adjusted Goodness of Fit Index (AGFI) & $\mathbf{0 . 9 3 7}$ \\
\hline Normed Fit Index (NFI) & $\cdot . \wedge$ ฯ \\
\hline Relative Fit Index (RFI) & $\mathbf{0 . 8 3 0}$ \\
\hline Incremental Fit Index (IFI) & $\mathbf{0 . 9 0 7}$ \\
\hline Tucker Lewis Index (TLI) & $\mathbf{0 . 8 9 7}$ \\
\hline Comparative Fit Index (CFI) & $\mathbf{0 . 9 0 7}$ \\
\hline Root Mean Square Residual Approximation $($ RMSEA) $<\mathbf{0 . 1 0}$ & $\mathbf{0 . 0 7 5}$ \\
\hline The average variance extracted & $\mathbf{0 . 8 5 8 2 7}$ \\
\hline
\end{tabular}

4. The average variance extracted for the constructs of MRP towards Production Operations planning (POP) with 0.786, MRP towards production Operations Controlling (POC) with 0.732, and Production Operation Planning towards Production Operations Control 0.607. i.e., there is a highly internal consistency based on the average inter-item correlation. AVEs of all scales turned out to be more than the cut-off values.

5. Overall, the evidence of a good model fit, reliability, and convergent validity, indicates that the measurement model should be improved for testing the regression model by excluding the variables of Master Production Scheduling (MPS), Rough Cut Capacity Planning (RCCP), Forecasts

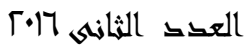

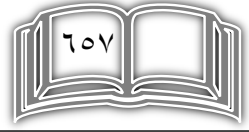

المجلد السابع 
MRP Framework to Increase Production Operations Performance....

Emad Elwy Habib

(Independent Demand), Bill of Material (Dependent Demand), Ordering Rules and inventory cycle (e.g. EOQ), and Production routing, excluded from the MRP Implementation measures construct. Accuracy of demand forecasting, and Total production maintenance (TPM), excluded from the Production Operations Planning Performance measures (POP) construct. Accuracy of completing production plan, Set-up time reduction, and Operations cost, excluded from the Production Operations Controlling Performance measures (POC) construct, from the initial CFA.

Hypotheses Multi-group analysis (Confirmatory Factor analysis and path analysis): Continuous Moderator Variables in Multiple Regression Analysis

H1: Egyptian Pharmatheutical companies with a higher level of MRP implementation have better production operational planning performance than those with a lower level of MRP implementation.

According to Karl L. Wuensch, (2016) A moderator variable is one which alters the relationship between other variables. It is commonly recommended that one center all of the variables involved in the interaction that is, subtract from each score on each variable the mean of all scores on that variable to reduce multicollinearity and other problems. We could center the criterion variable too, if we wanted to interpret scores on it in terms of deviations of the score from

العقد الثخانىى

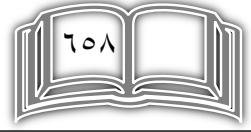

المجلد السابع 
MRP Framework to Increase Production Operations Performance....

Emad Elwy Habib

the mean. Centering the criterion variable would affect the intercept but not the other regression coefficients. We could just standardize our variables to $\mathrm{z}$ scores, which are, of course, centered. The standardization of all the variables means that $(B)$ regression coefficients will also be standardized.

According to Hayes (2013) the test of the interaction is absolutely unaffected by such transformations. Centering may, however, be useful with respect to making some of the regression coefficients have more meaningful interpretations than they otherwise would have. Our model is statistically significant, where all of the variables are standardized. Of most interest, the interaction term is statistically significant, $\mathrm{p}=0.049$, indicating that ethical idealism does function as a moderator of the relationship between The Level of Implementation of MRP misanthropy have a better impact on POP than POC. we could look at this interaction from another perspective that The high degree of Implementation of MRP Performance measures serves as a moderator of the relationship between POP and POC. According to Table (1), the researchers can conclude the following:

1. All standardized regression weights (factor loading) are greater than 0.50 , which means that most of the measured variables are statistically significant, i.e., the measured variables represent the constructs.
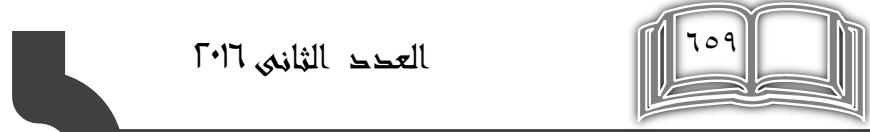
المجلك السابع 
MRP Framework to Increase Production Operations Performance....

Emad Elwy Habib

2. T-test for all measured variables is significant at a level of significance less than (0.001), which shows the importance of the observed variables in measuring the impact of corporate social responsibility on the employees' organizational affective commitment.

3. As a result of Squared Multiple Correlations, i.e., average variance extracted, for the variables less than (0.50), they have been excluded in both cases of High and Low MRP Implementation on: Production Operations Planning (POP) sub-constructs variables: effectiveness of production planning, information sharing degree of cross-function, flexibility of production planning, data accuracy of production planning, small lot sizing, JIT purchasing, pull production line, cross-training and multifunction employee, ' $5 \mathrm{~S}$ ' activities: workplace organization and standardization, KANBAN system, and production Rule and cycle (e.g. EPQ) from the initial CFA. Production Operations Control (POC) sub-constructs variables: Quality circle and TQM, Scheduling stability, level of WIP reduction, Degree of ontime delivery, and Satisfaction degree of quality.

\section{Measuring the Goodness of Fit of the (CFA) model:}

Table (4): The Goodness of Fit Indices of the Multi-Group for Confirmatory factor analysis and Path Analysis

\begin{tabular}{|l|l|}
\hline Chi-Square & 417.269 \\
\hline Degree of Freedom & 207 \\
\hline Level of Significance & 0.000 \\
\hline
\end{tabular}




\section{جامية تناة السويسه - كلية التجارة الإلسماعيلية}

MRP Framework to Increase Production Operations Performance....

Emad Elwy Habib

\begin{tabular}{|l|l|}
\hline Normed Chi-Square & 2.016 \\
\hline Root Mean Square Residual (RMR) <0.10 & 0.045 \\
\hline Goodness of Fit Index (GFI) & 0.932 \\
\hline Adjusted Goodness of Fit Index (AGFI) & 0.921 \\
\hline Normed Fit Index (NFI) &. .630 \\
\hline Relative Fit Index (RFI) & $\mathbf{0 . 5 7 1}$ \\
\hline Incremental Fit Index (IFI) & $\mathbf{0 . 7 7 1}$ \\
\hline Tucker Lewis Index (TLI) & $\mathbf{0 . 7 2 5}$ \\
\hline Comparative Fit Index (CFI) & $\mathbf{0 . 9 6 3}$ \\
\hline Root Mean Square Residual Approximation (RMSEA) <0.10 & $\mathbf{0 . 0 9 6}$ \\
\hline The mean variance extracted for all latent constructs & $\mathbf{0 . 9 2 9}$ \\
\hline
\end{tabular}

\section{From table (4), the researcher revealed that:}

1. All the goodness of fit tests of the model showed significant results or i.e., the majority of indicators at acceptable limits or near to cut-off values, and then the possibility of matching the actual form of the model estimated.

2. The values of Root Mean Square Residual (RMR) and Root Mean Square Residual Approximation (RMSEA) less than (0.10). the model indicates that (RMR), and (RMSEA) are 0.045 and 0.096 respectively, which indicates a close fit of the model in relation to the degrees of freedom

3. The mean variance extracted for all latent constructs is 0.929 , i.e., there is adequate convergent validity.

4. The average variance extracted for the constructs MRP implementation as a moderator in case of high MRP Implementation degree it was clear in the Multi-group analysis (confirmatory and path analysis), that POP explain POC by $26.1 \%$, with a $51 \%$ Standardized Regression Weights. This means that the implementation of MRP despite of it is a

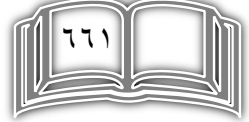

المجلك السابع 
MRP Framework to Increase Production Operations Performance....

Emad Elwy Habib

high or low implementation is significant impact on the production planning and controlling.

5. Overall, the evidence of a good model fit, reliability, and convergent validity, indicates that the measurement model should be improved for testing the regression model by excluding the following in both cases of High and Low MRP Implementation: POP sub-constructs variables: effectiveness of production planning, information sharing degree of crossfunction, flexibility of production planning, data accuracy of production planning, small lot sizing, JIT purchasing, pull production line, cross-training and multifunction employee, ' $5 \mathrm{~S}$ ' activities: workplace organization and standardization, KANBAN system, and production Rule and cycle (e.g. EPQ) from the initial CFA. POC sub-constructs variables: Quality circle and TQM, Scheduling stability, level of WIP reduction, Degree of on-time delivery, and Satisfaction degree of quality. This means that the Egyptian Pharmatheutical companies with a higher level of MRP implementation have better production operational planning performance than those with a lower level of MRP implementation, which is considered a full Examination for production operations management practices in the Egyptian Pharmatheutical Companies, and Reveals the progress of MRP application

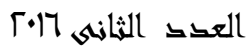

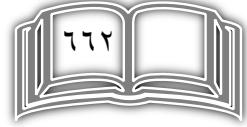

المجلك السابع 


\section{جاممة قناة السويسى - كلية التجارة الإلسماعيلية}

MRP Framework to Increase Production Operations Performance....

Emad Elwy Habib

Table (2): Multi-Group Analysis (Confirmatory Factor Analysis and Path Analysis by standardized and unstandardized regression weights: (High Unconstrained) Continuous Moderator $\mathrm{V}$
Analysis Andardized

\begin{tabular}{|c|c|c|c|c|c|c|c|}
\hline \multicolumn{3}{|c|}{ Path } & $\begin{array}{c}\text { Standardized } \\
\text { estimate }\end{array}$ & $\begin{array}{c}\text { Unstandardized } \\
\text { estimate }\end{array}$ & S.E.. & $\begin{array}{l}\text { t_test: } \\
\mathbf{C R}\end{array}$ & $\begin{array}{l}\text { Significaant } \\
\text { level }\end{array}$ \\
\hline POC & $<-$ & POP & .494 & 460 & .190 & 2.422 & 015 \\
\hline 92.2 & $<$ & POP & .543 & 1.000 & & & \\
\hline 92.13 & $3<-$ & POP & .675 & 1.405 & .389 & 3.615 & $\star \ldots$ \\
\hline 92.14 & $1<$ & POP & .757 & 1.632 & .424 & 3.850 & 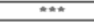 \\
\hline 92.15 & $8<-$ & POP & .793 & 1.408 & .357 & 3.939 & 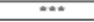 \\
\hline 92.16 & 0 & POP & .732 & 1.260 & .333 & 3.782 & $\cdots$ \\
\hline 92.17 & $\theta<-$ & POP & .573 & 976 & .299 & 3.260 & D01 \\
\hline 92.18 & $<<$ & POP & .427 & 662 & .252 & 2.629 & .009 \\
\hline 92.19 & $0<-$ & POP & .547 & 788 & .249 & 3.158 & 1002 \\
\hline 93.1 & $<-$ & POC & .547 & 1.000 & & & \\
\hline 93.2 & $<-$ & POC & .538 & 1.155 & .360 & 3.210 & $\$ 01$ \\
\hline 93.8 & $\Leftrightarrow$ & POC & .293 & 6332 & .323 & 1.954 & 051 \\
\hline q3.9 & $<-$ & POC & .580 & 1.246 & .368 & 3.38 .4 & $* * *$ \\
\hline 93.10 & $0<-$ & POC & $.8 s 9$ & 1.935 & .449 & 4.310 & $\ldots$ \\
\hline$q 3.11$ & $1<-$ & POC & .851 & 1.870 & .442 & 4.233 & 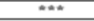 \\
\hline 93.12 & $2<-$ & POC & .665 & 1.357 & 367 & 3.699 & ma** \\
\hline q.3.13. & $3<-1$ & POC & .670 & 1.164 & .313 & 3.714 & $m+\infty$ \\
\hline
\end{tabular}

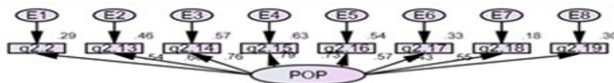

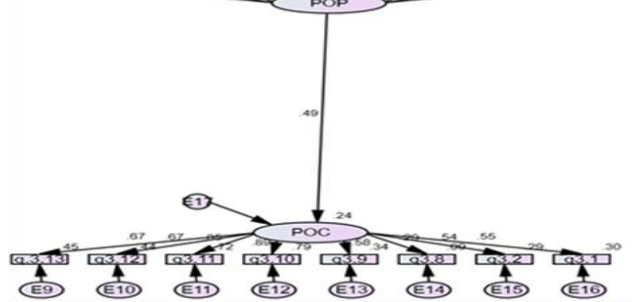

Figure (6): The Final Confirmatory facter analysis for a measurement model HIGH (HIGH - Unconstrained) - Estimates (HIGH - Unconstrained)
Table (3): ): Multi-Group Analysis (Confirmatory Factor Analysis and Path Analysis by standardized and unstandardized regression weights: Low - Unconstrained) Continuous Moderator Variables in Multiple Regression Analysis

\begin{tabular}{|c|c|c|c|c|c|c|c|}
\hline \multicolumn{3}{|c|}{ Path } & $\begin{array}{c}\text { Standlardized } \\
\text { estimate }\end{array}$ & $\begin{array}{l}\text { Unstandardized } \\
\text { estimate }\end{array}$ & S.E. & '-test: & $\begin{array}{c}\text { Significant } \\
\text { level }\end{array}$ \\
\hline POC & $k-1$ & POP & 0.510 & 1.000 & & & \\
\hline 92.2 & $k-1$ & POP & 0.567 & 1.000 & & & \\
\hline 92.13 & $6-1$ & POP & 0.547 & 1.1117 & 0.305 & 3.658 & 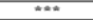 \\
\hline $\mathrm{q} 2.14$ & $6-1$ & POP & 0.721 & 1.830 & 0.395 & 4.639 & *n* \\
\hline$q 2.15$ & $k-1$ & POP & 0.739 & 1.550 & 0.327 & 4.7 .35 & 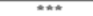 \\
\hline 92.16 & $<-1$ & POP & 0.850 & 2.202 & 0.417 & 5.278 & **** \\
\hline 92.17 & $6-1$ & POP & 0.859 & 2.142 & 0.403 & 5.318 & a*t* \\
\hline 92.18 & $k-1$ & POP & 0.620 & 1.258 & $0.30 \mathrm{~s}$ & 4.083 & 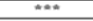 \\
\hline 92.19 & $k-1$ & POP & 0.409 & 0.740 & 0.264 & 2.800 & 0.005 \\
\hline q3.1 & $k-1$ & $P O C$ & 0.779 & 1.000 & & & \\
\hline 93.2 & $k-1$ & $\mathrm{POC}$ & 0.665 & 0.863 & 0.167 & 5.157 & ank \\
\hline 93.8 & $k-1$ & POC & 0.642 & 0.798 & 0.161 & 4.944 & $\cdots *$ \\
\hline q3.9 & $k-1$ & $P O C$ & 0.767 & 1.095 & 0.178 & 6.1138 & $\cdots$ \\
\hline 93.10 & $6-1$ & POC & 0.796 & 1.182 & 0.184 & 60.440 & $\ldots+$ \\
\hline q3.11 & $k-$ & $P O C$ & 0.679 & 0.750 & 0.142 & 5.287 & *ank \\
\hline 93.12 & $6-1$ & POC & 0.767 & 0.847 & 0.138 & 6.1147 & at+* \\
\hline 9.3.13 & $3-1$ & $\mathrm{POC}$ & 0.733 & 0.729 & 0.126 & 5.803 & ‥ \\
\hline
\end{tabular}

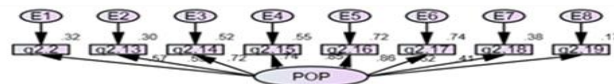

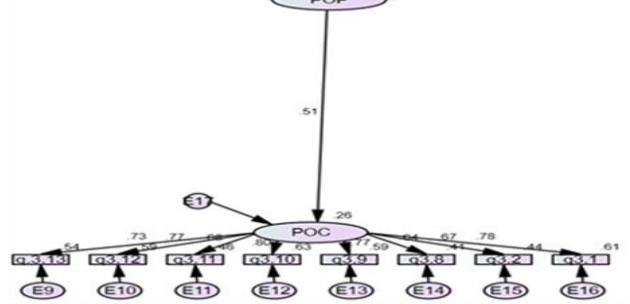
Figure (7): The Final Confirmatory factor analysis for a measurement model Low
(Low - Unconstrained)- Estimates (Low - Unconstrained)- Scalar Estimates (Low Unconstrained) - Minimum Likelihood Estimates

H2: MRP implementation in the Egyptian Pharmatheutical companies has a higher impact on production operational planning performance (POP) than Production Operations Control Performance.

According to the Multi-Group analysis (Confirmatory Factor Analysis and Path Analysis) in Figure (8), and Table (5), the researcher can conclude the following:

1. All standardized regression weights (factor loading) are greater than 0.50 , which means that all measured variables, 


\section{جامية تناة السويسه - كلية التجارة الإلسماعيلية}

MRP Framework to Increase Production Operations Performance....

Emad Elwy Habib

are statistically significant, i.e., the measured variables represent the all constructs: The Implementation of Materials Requirements Planning (MRP), Production Operation Planning Performance (POP), and Production Operations Controlling performance (POC).

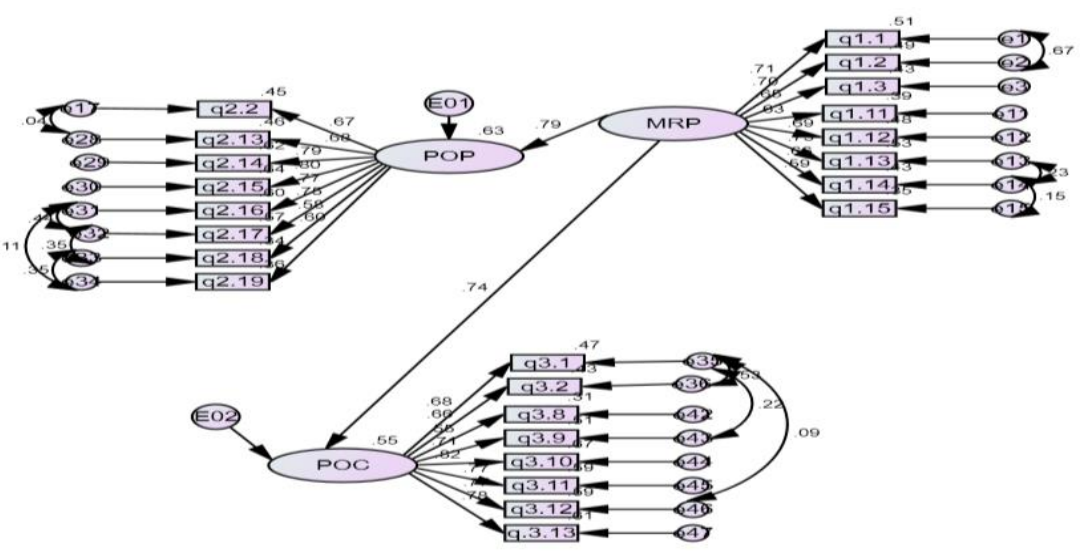

Figure (8): The Final Multi-Group for Confirmatory factor analysis and Path Analvsis for the Measurement Model

2. T-test for all measured variables is significant at a level of significance less than (0.001), which shows the importance of the observed variables in measuring the impact of corporate social responsibility on the employees' organizational affective commitment. 


\section{جاممة قناة السويسه - كلية التجارة الإلسماعيلية}

MRP Framework to Increase Production Operations Performance....

Emad Elwy Habib

Table (5): Multi-Group for Confirmatory factor analysis and Path Analysis by standardized and unstandardized regression weights

\begin{tabular}{|c|c|c|c|c|c|c|c|}
\hline \multicolumn{3}{|l|}{ Path } & $\begin{array}{l}\text { Standardized } \\
\text { estimate }\end{array}$ & $\begin{array}{l}\text { Unstandardized } \\
\text { estimate }\end{array}$ & S.E. & t_test:CR & $\begin{array}{l}\text { Significant } \\
\text { level }\end{array}$ \\
\hline POP & $\mid<--$ & MRP & .793 & .575 & .100 & 5.755 & $* * *$ \\
\hline POC & |<--- & MRP & .739 & .619 & .111 & 5.576 & $* * *$ \\
\hline$q 1.1$ & $\mid<--$ & MRP & .711 & 1.000 & & & \\
\hline$q 1.2$ & $\mid<--$ & MRP & 699 & .860 & .071 & 12.051 & $* * *$ \\
\hline q1.3 & $\mid<--$ & MRP & .654 & .882 & $\mid 138$ & 6.397 & $* * *$ \\
\hline$q 1.11$ & $\mid<--$ & MRP & .627 & 780 & $\mid .127$ & 6.135 & $* * *$ \\
\hline$q 1.12$ & $\mid<--$ & MRP & 690 & .876 & 130 & 6.729 & $* * *$ \\
\hline$q 1.13$ & $\mid<--$ & MRP & .728 & .866 & .123 & 7.065 & $* * *$ \\
\hline$q 1.14$ & $<--$ & MRP & .659 & .742 & .116 & 6.383 & $* * *$ \\
\hline$q 1.15$ & $\mid<--$ & MRP & .588 & .710 & .123 & 5.754 & $* * *$ \\
\hline q2.19 & $\mid<--$ & POP & 601 & .834 & 146 & 5.704 & $* * *$ \\
\hline q2.18 & $<--$ & POP & .583 & .846 & .152 & 5.557 & $* * *$ \\
\hline$q 2.17$ & $<--$ & POP & .754 & 1.297 & .186 & 6.976 & $* * *$ \\
\hline$q 2.16$ & |<-- & POP & .775 & 1.319 & .185 & 7.122 & **** \\
\hline$q 2.15$ & $<--$ & POP & .798 & 1.213 & 166 & 7.325 & $* * *$ \\
\hline q2.14 & $<--$ & POP & .786 & 1.397 & .193 & 7.234 & ***** \\
\hline$q 2.13$ & $<--$ & POP & 679 & 1.061 & 162 & 6.538 & $* * *$ \\
\hline $\mathrm{q} 2.2$ & $<--$ & POP & .674 & 1.000 & & & \\
\hline q3.1 & $<-$ & POC & 683 & 1.000 & & & \\
\hline q3.2 & $<--$ & POC & .659 & 1.024 & .112 & 9.164 & **** \\
\hline q3.8 & $<--$ & POC & .555 & .800 & .149 & 5.383 & **** \\
\hline q3.9 & $<-$ & POC & .711 & 1.108 & .145 & 7.657 & $* * *$ \\
\hline$q 3.10$ & $\mid<--$ & POC & .817 & 1.320 & 173 & 7.628 & F*** \\
\hline
\end{tabular}

العق

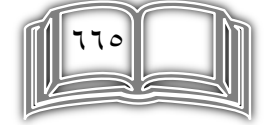

المجلد السابع 
جامية تأزة السويسه - كلية التجارة الإلسماعيلية

MRP Framework to Increase Production Operations Performance....

Emad Elwy Habib

\begin{tabular}{|c|c|c|c|c|c|c|}
\hline \multicolumn{2}{|l|}{ Path } & $\begin{array}{l}\text { Standardized } \\
\text { estimate }\end{array}$ & $\begin{array}{l}\text { Unstandardized } \\
\text { estimate }\end{array}$ & S.E. & t_test:CR & $\begin{array}{l}\text { Significant } \\
\text { level }\end{array}$ \\
\hline q3.11 & $\mid<---$ POC & .766 & 1.074 & .149 & 7.218 & $* * *$ \\
\hline q3.12 & <--- POC & .771 & 1.063 & .139 & 7.630 & $* * *$ \\
\hline q.3.13 & <--- POC & .779 & .956 & .130 & 7.324 & $* * *$ \\
\hline
\end{tabular}

*** Significant at level less than (0.001). a: Initial value for the possibility of solving equations.

3. As a result of Squared Multiple Correlations, i.e., average variance extracted, for the variables of the constructs have less than (0.50), then they have been excluded form: Materials Requirement Planning (MRP): Capacity Requirement Planning (CRP), Shop flow scheduling and control, Inventory management, Purchasing/supplier management, Equipment maintenance management, Basic data management, Forecasts (Independent Demand), and Bill of Material (Dependent Demand). Production Operations Planning Performance (POP): Effectiveness of production planning, Information sharing degree of cross-function, Flexibility of production planning, Data accuracy of production planning, Small lot sizing, JIT purchasing, Pull production line, Cross-training and multifunction employee, ' $5 \mathrm{~S}$ ' activities: workplace organization and standardization, KANBAN system, and Production Rule and cycle (e.g. EPQ). Production Operations Controlling Performance (POC): Quality circle and TQM, Scheduling stability, level of WIP reduction, Degree of on-time delivery, and Satisfaction degree of quality

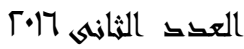

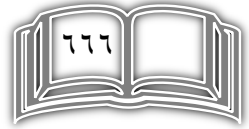

المجلك السابع 
MRP Framework to Increase Production Operations Performance....

Emad Elwy Habib

\section{Measuring the Goodness of Fit of the (CFA) model:}

According to table (6), the researcher revealed that:

1. All the goodness of fit tests of the model showed significant results or i.e., the majority of indicators at acceptable limits or near to cut-off values, and then the possibility of matching the actual form of the model estimated.

2. the values of Root Mean Square Residual (RMR) and Root Mean Square Residual Approximation (RMSEA) less than $(0.10)$, which indicates a close fit of the model in relation to the degrees of freedom

3. The mean variance extracted for all latent constructs is 0.866 , i.e., there is adequate convergent validity.

Table (6): The Goodness of Fit Indices of Multi-Group for Confirmatory factor analysis and Path Analysis

\begin{tabular}{|l|l|}
\hline Chi-Square & 502.495 \\
\hline Degree of Freedom & 239 \\
\hline Level of Significance & $\mathbf{0 . 0 0 0}$ \\
\hline Normed Chi-Square & 2.102 \\
\hline Root Mean Square Residual (RMR) <0.10 & $\mathbf{0 . 0 4 2}$ \\
\hline Goodness of Fit Index (GFI) & $\mathbf{0 . 9 4 1}$ \\
\hline Adjusted Goodness of Fit Index (AGFI) & $\mathbf{0 . 9 2 8}$ \\
\hline Normed Fit Index (NFI) & $\mathbf{. 7 4 5}$ \\
\hline Relative Fit Index (RFI) & $\mathbf{0 . 7 0 6}$ \\
\hline Incremental Fit Index (IFI) & $\mathbf{0 . 8 4 8}$ \\
\hline Tucker Lewis Index (TLI) & $\mathbf{0 . 9 2 8}$ \\
\hline Comparative Fit Index (CFI) & $\mathbf{0 . 8 4 5}$ \\
\hline $\begin{array}{l}\text { Root Mean Square Residual Approximation (RMSEA) } \\
<0.10\end{array}$ & $\mathbf{0 . 8 9 0}$ \\
\hline The mean variance extracted for all latent constructs & $\mathbf{0 . . 8 6 6}$ \\
\hline
\end{tabular}

العك

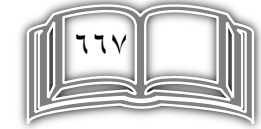

المجلد السابي 
MRP Framework to Increase Production Operations Performance....

Emad Elwy Habib

4. The average variance extracted for the constructs of Materials Requirements Planning (MRP) Towards; Production Operations Planning Performance (POP), and Production Operations Controlling Performance (POC) are: (0.793), (0.739), respectively, i.e., there is a highly internal consistency based on the average inter-item correlation. AVEs of all scales turned out to be more than the cut-off values.

Overall, the evidence of a good model fit, reliability, and convergent validity, indicates that the measurement model should be improved for testing the regression model by excluding the variables of Materials Requirement Planning (MRP): Capacity Requirement Planning (CRP), Shop flow scheduling and control, Inventory management, Purchasing/supplier management, Equipment maintenance management, Basic data management, Forecasts (Independent Demand), and Bill of Material (Dependent Demand). Production Operations Planning Performance (POP): Effectiveness of production planning, Information sharing degree of cross-function, Flexibility of production planning, Data accuracy of production planning, Small lot sizing, JIT purchasing, Pull production line, Cross-training and multifunction employee, ' $5 \mathrm{~S}$ ' activities: workplace organization and standardization, KANBAN system, and Production Rule and cycle (e.g. EPQ), which gives a full Investigation for the relationships among MRP technique components and its impact on production operations planning performance. Production Operations Controlling 
MRP Framework to Increase Production Operations Performance....

Emad Elwy Habib

Performance (POC): Quality circle and TQM, Scheduling stability, level of WIP reduction, Degree of on-time delivery, and Satisfaction degree of quality from the initial CFA, which confirms that MRP implementation in the Egyptian Pharmatheutical companies has a higher impact on production operational planning performance (POP) than Production Operations Control Performance, but the difference is not that high, so that addresses a full Investigation for the relationships among MRP technique components and its impact on production operations control performance.

\section{H3: MRP have a significant positive impact on the Production operations performance in the Egyptian Pharmatheutical companies.}

According to the Multi-Group analysis (Confirmatory Factor Analysis and Path Analysis) Figure (8), and Table (7), the researcher can conclude the following:

1. All standardized regression weights (factor loading) are greater than 0.50 , which means that all measured variables, are statistically significant, i.e., the measured variables represent the two constructs Materials Requirements Planning MRP, and Production and Operations Performance with an overall estimate of 0.942 . 


\section{جامية تناة السويسه - كلية التجارة الإلسماعيلية}

MRP Framework to Increase Production Operations Performance....

Emad Elwy Habib
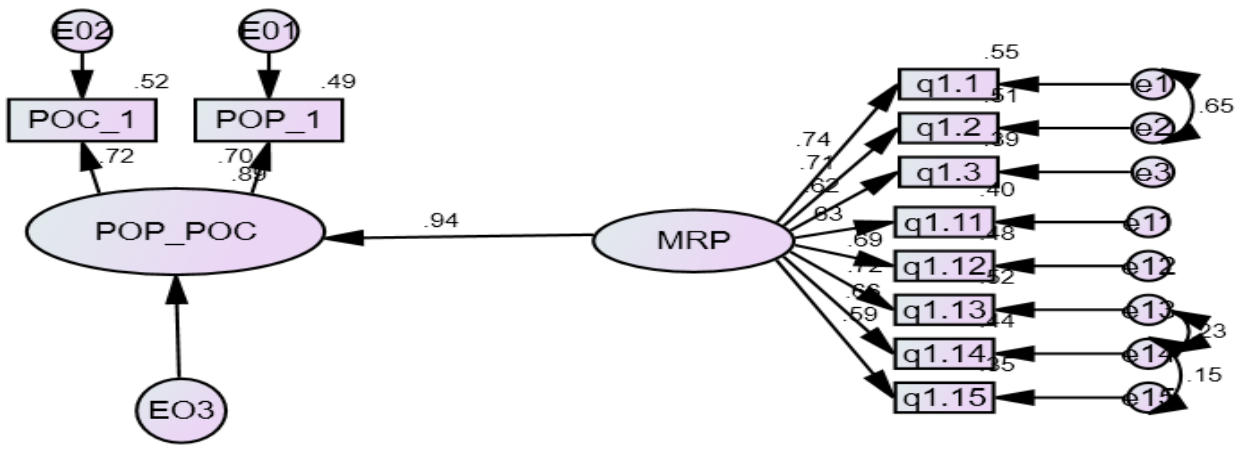

Figure (9): The Final Multi-Group for Confirmatory factor analysis and Path Analysis for the Measurement Model

Table (7): Multi-Group for Confirmatory factor analysis and Path Analysis by standardized and unstandardized regression weights

\begin{tabular}{|c|c|c|c|c|c|c|c|}
\hline \multicolumn{3}{|l|}{ Path } & \multirow{2}{*}{\begin{tabular}{|l||}
$\begin{array}{l}\text { Standardized } \\
\text { estimate }\end{array}$ \\
.942
\end{tabular}} & \multirow{2}{*}{\begin{tabular}{|l||}
$\begin{array}{l}\text { Unstandardized } \\
\text { estimate }\end{array}$ \\
.629
\end{tabular}} & \multirow{2}{*}{\begin{tabular}{|c|} 
S.E. \\
.093 \\
\end{tabular}} & \multirow{2}{*}{\begin{tabular}{||l} 
t_test:CR \\
6.739
\end{tabular}} & \multirow{2}{*}{$\begin{array}{l}\text { Significant } \\
\text { level } \\
* * *\end{array}$} \\
\hline POP_POC & $<--$ & MRP & & & & & \\
\hline q1.1 & $\mid<--$ & MRP & .740 & 1.000 & & & \\
\hline$q 1.2$ & $<--$ & MRP & .712 & .841 & .069 & 12.258 & $* * *$ \\
\hline$q 1.3$ & $<--$ & MRP & .621 & .804 & .130 & 6.208 & $* * *$ \\
\hline$q 1.11$ & $\mid<---$ & MRP & .634 & .758 & .120 & 6.334 & $* * *$ \\
\hline$q 1.12$ & $\mid<--$ & MRP & .694 & .848 & .122 & 6.950 & $* * *$ \\
\hline$q 1.13$ & $\mid<---$ & MRP & .720 & .824 & .115 & 7.186 & $* * *$ \\
\hline$q 1.14$ & $\mid<---$ & MRP & .665 & .720 & .109 & 6.573 & $* * *$ \\
\hline$q 1.15$ & $\mid<--$ & MRP & .588 & .683 & .117 & 5.850 & $* * *$ \\
\hline POC_1 & $\mid<--$ & POP_POC & .720 & 1.000 & & & \\
\hline POP_1 & $|<---|$ & POP_POC & .697 & .904 & .139 & 6.482 & $* * *$ \\
\hline
\end{tabular}

*** Significant at level less than (0.001). a: Initial value for the possibility of solving equations.

العك

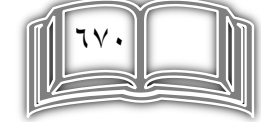

المجلد السابي 
MRP Framework to Increase Production Operations Performance....

Emad Elwy Habib

2. t-test for all measured variables is significant at a level of significance less than (0.001), which shows the importance of the observed variables in measuring the impact of The Implementation of Materials Requirements Planning on the overall Production Operations Performance.

3. As a result of Squared Multiple Correlations, i.e., average variance extracted, for the variables of MRP; Capacity Requirement Planning (CRP), Shop flow scheduling and control, and Inventory management, have less than $(0.50)$, then they have been excluded from the Implementation of Materials Requirement Planning MRP on the overall Production and Operations Performance with an overall estimate of 0.888 .

\section{Measuring the Goodness of Fit of the (CFA) model:}

Table (8): The Goodness of Fit Indices of Multi-Group for Confirmatory factor analysis and Path Analysis

\begin{tabular}{|l|l|}
\hline Chi-Square & 128.936 \\
\hline Degree of Freedom & 31 \\
\hline Level of Significance & 0.000 \\
\hline Normed Chi-Square & 4.159 \\
\hline Root Mean Square Residual (RMR) <0.10 & $\mathbf{0 . 0 4 0}$ \\
\hline Goodness of Fit Index (GFI) & $\mathbf{0 . 9 2 8}$ \\
\hline Adjusted Goodness of Fit Index (AGFI) & $\mathbf{0 . 9 1 7}$ \\
\hline Normed Fit Index (NFI) & .800 \\
\hline Relative Fit Index (RFI) & $\mathbf{0 . 7 1 0}$ \\
\hline Incremental Fit Index (IFI) & $\mathbf{0 . 8 4 1}$ \\
\hline Tucker Lewis Index (TLI) & $\mathbf{0 . 7 6 3}$ \\
\hline Comparative Fit Index (CFI) & $\mathbf{0 . 9 7 3}$ \\
\hline $\begin{array}{l}\text { Root Mean Square Residual Approximation (RMSEA) } \\
<0.10\end{array}$ & $\mathbf{0 . 0 6 9}$ \\
\hline The average variance extracted & $\mathbf{0 . 8 8 9}$ \\
\hline
\end{tabular}


MRP Framework to Increase Production Operations Performance....

Emad Elwy Habib

\section{From table (8), the researcher revealed that:}

1. All the goodness of fit tests of the model showed significant results or i.e., the majority of indicators at acceptable limits or near to cut-off values, and then the possibility of matching the actual form of the model estimated.

2. the values of Root Mean Square Residual (RMR) and Root Mean Square Residual Approximation (RMSEA) less than (0.10), which indicates a close fit of the model in relation to the degrees of freedom

3. The mean variance extracted for all latent constructs is 0.8890 , i.e., there is adequate convergent validity.

4. The average variance extracted for the constructs of Implementation of Materials Requirement Planning on the overall Production and Operations Performance (0.942), i.e., there is a highly internal consistency based on the average inter-item correlation. AVEs of all scales turned out to be more than the cut-off values.

5. Overall, the evidence of a good model fit, reliability, and convergent validity, indicates that the measurement model should be improved for testing the regression model by excluding the variables of MRP; Capacity Requirement Planning (CRP), Shop flow scheduling and control, and Inventory management, from the initial CFA, which confirms that MRP construct have a significant positive impact on the Production 
MRP Framework to Increase Production Operations Performance....

Emad Elwy Habib

operations performance in the Egyptian Pharmatheutical companies.

\section{Recommendations:}

Based on the conclusion of the three hypotheses and the outcomes of the Multi-Group for Confirmatory factor analysis and Path Analysis Models, the high Implementation of the sub-constructs of Materials Requirements Planning, Production operations planning, and production operations controlling constructs respectively are significant but needs to be developed throughout considering a high implementation of the following excluded sub-constructs:

\section{Materials Requirement Planning (MRP): Capacity} Requirement Planning (CRP), Shop flow scheduling and control, Inventory management, Purchasing/supplier management, Equipment maintenance management, Basic data management, demand forecasts, and demand Bill of Material.

\section{Production Operations Planning Performance (POP):}

Effectiveness of production planning, Information sharing degree of cross-function, Flexibility of production planning, Data accuracy of production planning, Small lot sizing, JIT purchasing, Pull production line, Cross-training and multifunction employee, '5S' activities: workplace organization and standardization, KANBAN system, and Production Rule and cycle (e.g. EPQ).

\section{Production Operations Controlling Performance (POC):}

Quality circle, Scheduling stability, level of WIP reduction, Degree of on-time delivery, and Satisfaction degree of quality from the

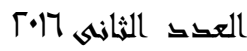

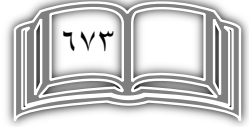

المجلك السابع 
MRP Framework to Increase Production Operations Performance.... Emad Elwy Habib

initial CFA. To the researcher's opinion, Production Operations Performance of the Egyptian Manufacturing Pharmatheutical Companies in Egypt will be maximized through a higher implementation of MRP full model, which presents insightful recommendations for further efficiency improvement. 
MRP Framework to Increase Production Operations Performance....

Emad Elwy Habib

\section{References:}

1. Alfieri, A., Tolio, T., \& Urgo, M. (2012). A project scheduling approach to production and material requirement planning in Manufacturing-toOrder environments. Journal of Intelligent Manufacturing, 23(3),575578.

2. Anderson, J.C., et al. (1982) 'Materials requirements planning systems: the state of the art', Production and Inventory Management, Vol. 23, No. 4, pp.51-66.

3. Benton, W.C. and Shin, H. (1998) 'Manufacturing planning and control: the evolution of MRP and JIT integration', European Journal of Operational Research, Vol. 110, pp.411-440.

4. Bose, G.J. and Rao, A. (1988) 'Implementation JIT with MRPII creates hybrid manufacturing environment', Industrial Engineering, Vol. 20, No. 9, pp.49-54.

5. Chan, J.W.K. and Burns, N.D. (2002) 'Benchmarking manufacturing planning and control (MPC) systems-an empirical study of Hong Kong supply chains', Benchmarking: An International Journal, Vol. 9, No. 3, pp.256-277.

6. Chen, Z., \& Shang, J. S. (2008). Manufacturing planning and control technology versus operational performance: an empirical study of MRP and JIT in China. International Journal of Manufacturing Technology and Management, 13(1), 4-29.

7. Fullerton, R.R. and McWatters, C.S. (2001) 'The production performance benefits from JIT implementation', Journal of Operations Management, Vol. 19, No. 1, pp.81-96.

8. Fullerton, R.R. and McWatters, C.S. (2002) 'The role of performance measures and incentive systems in relationship to the degree of JIT
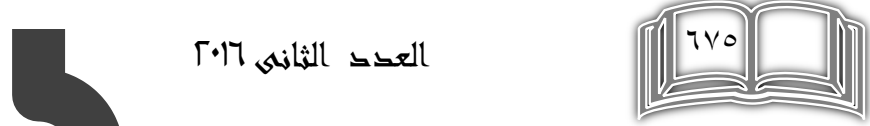

المجلد السابع 
MRP Framework to Increase Production Operations Performance....

Emad Elwy Habib

implementation', Accounting, Organizations and Society, Vol. 27, pp.711-

9. Fullerton, R.R., McWatters, C.S. and Fawson, C. (2003) 'An examination of the relationships between JIT and financial performance', Journal of Operations Management, Vol. 21, No. 4, pp.383-404.

10. Hunton, J.E, Lippincott, B. and Reck, J.L. (2003) 'Enterprise resource planning systems: comparison firm performance of adopters and nonadopters', International Journal of Accounting Information systems, Vol. 4, pp.165-184.

11. Ismail, S. (2005). An investigation of MRP benefit-determinant relationships: ACE model. Problems and Perspectives in Management, 2, 80-98.

12. Jha, Vaibhav (2012). MRP-JIT Integrated Production System, International Journal of Engineering Research and Applications, Vol. 2, Issue4, pp.2377-2387

13. John, D. and Roberts, H. (1994) 'Success and failure of MRPII implementation', British Journal of Management, Vol. 5, pp.221-240.

14. Jyh, H. (2008). Exploring the compatibility of dampening procedures and lot-sizing rules in MRP systems under uncertain operating environments. International Journal of Production Research, 46(18), p. 5097-5105.

15. Kim, K. (2014). Material Resource Planning (MRP): Will You Need MRP without the Customer? Open Journal of Social Sciences, 2(04), 256.

16. Lau, R.S.M., Zhao, X. and Lai, F. (2002) 'Survey of MRPII implementation and benefits in mainland China and Hong Kong', Production and Inventory Management Journal, Vol. 43, Nos. 3/4, pp.65-71.
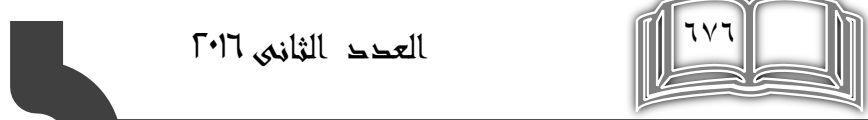

المجلد السابع 
MRP Framework to Increase Production Operations Performance....

Emad Elwy Habib

17. Lee, C.Y. (1992) 'A recent development of the integrated manufacturing system: a hybrid of MRP and JIT', International Journal of Operations and Production Management, Vol. 13, No. 4, pp.3-17.

18. Murphy, K.E. and Simon, S.J. (2002) 'Intangible benefits valuation in ERP projects', Information Systems Journal, Vol. 12, pp.301-320.

19. Petroni, A. (2002) 'Critical factors of MRP implementation in small and medium-sized firms', International Journal of Operations and Production Management, Vol. 22, No. 30, pp.329-348.

20. Petroni, A. and Braglia, M. (1999) 'Shortcomings and benefits associated with the implementation of MRP packages: a survey research', Logistics Information Management, Vol. 12, No. 6, pp.428438.

21. Pyke, D., Farley, J. and Robb, D. (2002) 'Manufacturing technology and operations in China: a survey of state-owned enterprises, private firms, joint ventures and wholly-owned foreign subsidiaries', European Management Journal, Vol. 20, No. 4, pp.356-375.

22. Rusănescu, M. (2014). Materials Requirements Planning, Inventory Control System in Industry. Magazine of Hydraulics, Pneumatics, Tribology, Ecology, Sensorics, Mechatronics, 1453 - 7303, 21-24.

23. Salaheldin, S.I. (2004) 'Factors influencing the stage of MRP implementation: an empirical study', Problems and Perspectives in Management, Vol. 3, pp.89-102.

24. Salaheldin, S.I. and Francis, A. (1998) 'A study on MRP practices in Egyptian manufacturing companies', International Journal of Operations and Production Management, Vol. 18, No. 6, pp.588-611.

25. Schroeder, R.G., et al. (1981) 'A study of MRP benefits and costs', Journal of Operations Management, Vol. 2, No. 1, pp.1-9.
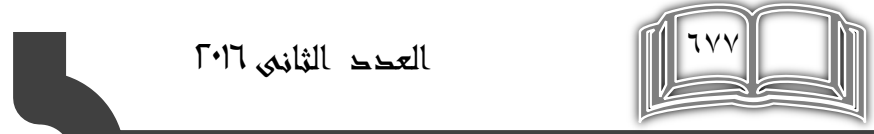

المجلد السابي 
MRP Framework to Increase Production Operations Performance.... Emad Elwy Habib

26. Sillince, J.A.A. and Sykes, G.M.H. (1993) 'Integrating MRPII and JIT: a management rather than a technical challenge', International Journal of Operations and Production Management, Vol. 13, No. 4, pp.18-31.

27. Sum, C.C., et al. (1995) 'An analysis of material requirements planning (MRP) benefits using alternating conditional expectation (ACE)', Journal of Operations Management, Vol. 13, No. 1, pp.35-58.

28. Titone, C.R. (1994) 'Integrating MRPII and JIT to achieve world-class status', Hospital Materiel Management Quarterly, Vol. 15, No. 4, pp.6266.

29. Toni, A.D., Caputo, M. and Vinelli, A. (1988) 'Production management techniques: push-pull classification and application condition', International Journal of Operations and Production Management, Vol. 8, No. 2, pp.35-51.

30. Wang, L.L. et al. (2005) 'Investigation and analysis of MRPII application in Chinese enterprise', Chinese Mechanical Engineering (in Chinese), No. 2, pp.65-68.

31. White, E.M., Anderson, J.C. and Scheroeder, R.G. et al. (1982) 'A study of MRP implementation process', Journal of Operations management, Vol. 2, No. 3, pp.145-153.

32. Wilson, F., Yusuf, Y.Y. and Little, D. (1998) 'An empirical investigation of enterprise-wide integration of MRPII', International Journal of Operations and Production Management, Vol. 18, No. 1, pp.66-86.

33. Zhang, H.B. et al. (1998) 'Investigation of MRPII application', Information of education (in Chinese), No. 5, pp.7-10.

34. Zhao, X., Lai, F. and Young, S. (2002) 'A study of manufacturing resources planning (MRPII) implementation in China', International Journal of Production Research, Vol. 40, No. 14, pp.3461-3478. 